\title{
The family Nicoletiidae in the Canary Islands, with description of new taxa (Insecta: Zygentoma)
}

\author{
Rafael MOlero baltanÁS ${ }^{1}$, Miquel GAJU RiCART ${ }^{1}$, Néstor LÓPEZ DOS SANTOS ${ }^{2}$, Pedro OROMÍ ${ }^{3}$ \\ and CARMEN BACH DE ROCA ${ }^{4}$ \\ ${ }^{1}$ Departamento de Zoología, Universidad de Córdoba, Edificio C-1 (C. Darwin), Campus de Rabanales, 14071 Córdoba, Spain; \\ e-mails: ba1mobar@uco.es; ba1garim@uco.es \\ ${ }^{2} \mathrm{C} /$ Portugal 74 1º, 35010 Las Palmas de Gran Canaria, Spain; e-mail: nlopez@cifor.net \\ ${ }^{3}$ Departamento de Biología Animal, Universidad de La Laguna, 38205 La Laguna, Tenerife, Islas Canarias, Spain; \\ e-mail: poromi@ull.es \\ ${ }^{4}$ Departamento de Biología Animal, Biología Vegetal y Ecología, Universidad Autónoma de Barcelona, 08193 Bellaterra, Barcelona, \\ Spain; e-mail: Carmen.Bach@uab.es
}

Key words. Nicoletiidae, Canary islands, Canariletia gen. n., Coletinia majorensis sp. n., taxonomy, Coletiniinae, troglobionts

\begin{abstract}
The knowledge of the family Nicoletiidae in the Canary Islands was limited to two reports of Proatelurina pseudolepisma (Grassi, 1887), a species which belongs to the subfamily Atelurinae. This study provides new data on the occurrence of representatives of Nicoletiidae on these islands and descriptions of two endemic troglobic taxa: Canariletia holosterna gen. n. et sp. n., from the island of Gran Canaria, and Coletinia majorensis sp. n., found in Fuerteventura. The latter belongs to a group of species whose males have asymmetric antennae, so it is compared with those Coletinia of this group. Canariletia gen. n. shows a unique combination of characters inside Nicoletiidae, so its position within this family is discussed, considering the new genus as incertae sedis, but probably related to the Palaearctic and Afrotropical genera included in the subfamily Coletiniinae sensu Mendes, 1988.
\end{abstract}

\section{INTRODUCTION}

The family Nicoletiidae includes eyeless Zygentoma (= Thysanura s. str.) living in warm regions of the world, mainly in caves and endogean environments, or associated with ants or termites. Since the revisions of Nicoletiidae made by Mendes (1988 and 2002) this family is subdivided into five subfamilies. In the Western Palaearctic region only the subfamilies Coletiniinae and Atelurinae have been reported until now (the occurrence of Nicoletia Gervais, 1843 - subfamily Nicoletiinae - in Europe is probably due to accidental introductions).

The Zygentoma fauna of the Canary Islands is reported in several publications (Ridley, 1881; Navás, 1906; Silvestri, 1940; Wygodzinsky, 1952; Paclt, 1966; Mendes, 1982 , 1993; Mendes et al., 1992, 1993; Molero et al., 1999), but only representatives of the family Lepismatidae are cited for this archipelago, with the exception of two records of the species Proatelurina pseudolepisma (Grassi, 1887) which was cited for Tenerife by Mendes (1993) as Proatelura pseudolepisma, and for La Palma by Mendes et al. (1993). This species is mainly myrmecophilous and is widespread around the Mediterranean region; probably its presence in the Canary Islands is due to an accidental introduction (as is the case for some myrmecophilous Lepismatidae such as the Mediterranean Neoasterolepisma wasmanni (Moniez, 1897) that has been reported for Peru (Wygodzinsky, 1967). Many populations of Proatelurina are only represented by females, so they are probably parthenogenetic; the finding of only female specimens in the Canarian archipelago suggests that these insects may fol- low this way of reproduction (Mendes et al., 1993). The genus Proatelurina belongs to the subfamily Atelurinae, which was considered as an independent family when $P$. pseudolepisma was cited for the Canary Islands. The status of Proatelurina as an independent genus was established by Paclt (1963), who separated it from the Oriental species Proatelura jacobsoni (Silvestri, 1911). This split has been accepted from 1993 to the present, as can be seen in the recent revision of Atelurinae by Mendes (2012).

Recently, some material of Zygentoma has been collected in caves on this archipelago, containing only samples of troglobiont Nicoletiidae from two islands: Gran Canaria (a new genus and species) and Fuerteventura (a new species of Coletinia Wygodzinsky, 1980). The two new taxa, described below, represent the first record of non-atelurine Nicoletiidae for the Canarian archipelago and the Macaronesian region.

\section{MATERIAL AND METHODS}

Specimens preserved in $70 \%$ ethanol were dissected and mounted in Tendeiro medium (see Molero et al., 2000) for microscopic study. Illustrations were made with the aid of a camera lucida attached to a microscope. Metric data follow the criteria given in Smith (1998). One specimen of Canariletia gen. n. was prepared for SEM by dehydrating it with ethanol and hexamethyldisilazane (following Ubero-Pascal et al., 2005) and coating it with gold.

The types of the new species are deposited at the following institutions: UCO - Departamento de Zoología, Universidad de Córdoba (Córdoba, Spain); DZUL - Departamento de Zoología, Universidad de La Laguna (Tenerife, Canary Islands, Spain); 


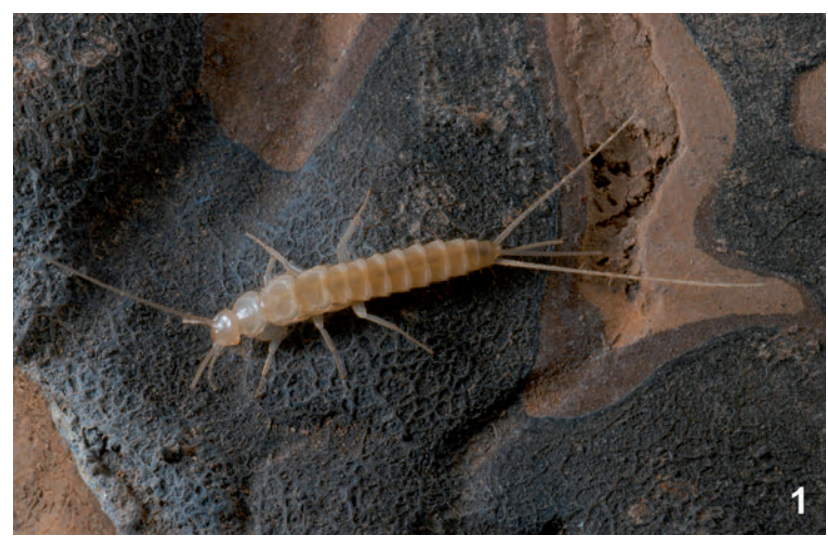

Fig. 1. Coletinia majorensis sp. n. Photographed by P. Oromí in its natural habitat in Cueva del Llano (Fuerteventura island).

MNCN - Museo Nacional de Ciencias Naturales (Madrid, Spain); IICT - Instituto de Investigação Científica Tropical, Zoology collection curated by L. F. Mendes (Lisbon, Portugal).

\section{RESULTS}

Canariletia Molero, Gaju, López \& Bach gen. n.

Type species. Canariletia holosterna $\mathrm{sp}$. $\mathrm{n}$. by present designation.

\section{Description}

Habitus as in Fig. 2; colour photographs published by M. Naranjo and P. Oromí can be seen in Naranjo et al. (2009), pages 33 and 81. Small size, length of adults up to $7.1 \mathrm{~mm}$. Body shape subcylindrical, thorax nearly as wide as the abdomen, slightly detaching from abdomen base. Epidermic pigment pale yellowish; specimens preserved in alcohol become whitish. All surfaces covered with scales, except for appendages (antennae, maxillary and labial palps, terminal filaments and legs; although coxae are scaled). These scales are ovoid to subquadrangular, with convex and rounded distal margins and numerous subparallel rays (Fig. 3). Corresponding to the dense cover of scales, the body surface shows a poor setation, with the disc of the tergites and sternites almost devoid of setae.

Antennae and caudal filaments a bit shorter than body length. Antennae of males symmetric, the pedicel with an apical triangular apophysis which shows a dense field of glandular projections in its inner side (Figs 4 and 7). Antennae of females with shorter pedicel, lacking apophysis and with five long bifid macrosetae. Mandibles with well developed sclerotized teeth, a molar plate and few setae (Fig. 8). Galea with two apical sensory cones; lacinia with prostheca and a bifurcate tip (Fig. 6). Maxillary palps with 5 segments (Fig. 9), the last one with 6 apical sensory rods and subcircular sensilla. Terminal segment of the labial palps with 6 sensory papillae arranged in a subcircular group; lateral margins of this segment with some basiconic sensilla (Figs 5 and 10).

Nota with many marginal setae on lateral borders and posterolateral angles, the pronotum also bears these setae on its anterior margin. Some of them are long bifid macrosetae, the remaining are short bristles. The disc of the nota is nearly bare, with only few small setae (Fig. 11). Tarsi 4-segmented, longer than their respective tibiae (Fig. 12). Praetarsus with 3 simple claws, the median one thinner and nearly as long as the lateral ones, these with thickened bases (Fig. 14).

Urotergites with fine sutures separating their lateral portions; they are hardly visible under the cover of scales, but in a similar position to that drawn for Coletinia by Wygodzinsky (1980); the hind margin with setae and macrosetae irregularly arranged (Fig. 15). Urotergite X of males (Fig. 16) with a concave hind border but without prominent posterolateral lobes and devoid of sensorial pegs (these pegs are also absent in terminal filaments). This tergite has a similar shape (only slightly less concave) and setation in females, showing only a few setae and $1+1$ spines on the posterior margin and lacking setae on the disc (Fig. 17).

All urosternites entire, without divisions into sternite and coxites; the first urosternite, divided in previously known Palaearctic genera, is also entire in this new genus (Fig. 18). Urosternites II-IX with a pair of styli (Fig. 19). Urosternites II-VI with exsertile vesicles and VII with pseudovesicles. Coxites of male free; parameres wide, subcylindrical to ovoid and without divisions. Penis small and with longitudinal opening (Fig. 21). Subgenital plate well developed (Fig. 23). Ovipositor long, surpassing styli IX (Fig. 24). Gonapophyses IX with spinulated inner distal area (Fig. 25).

Etymology. The name Canariletia is based on that of the island of Gran Canaria, with the same ending as Nicoletia, the type genus of the family Nicoletiidae. Gender: Feminine.

\section{Canariletia holosterna Molero, Gaju, López \& Bach sp. $\mathbf{n}$.}

\section{Description}

Body length: $6.1 \mathrm{~mm}$ (holotype); up to $6.5 \mathrm{~mm}$ in the biggest males, up to $7.1 \mathrm{~mm}$ in the biggest females collected. Antenna: maximum preserved length up to $6.1 \mathrm{~mm}$. Terminal filaments up to $5.1 \mathrm{~mm}$ (maximum preserved length, probably broken).

Epidermal pigment and scales as described for the genus. Head with very few setae: only some marginal long bifid macrosetae inserted on the ocular region and near the margin of the frons (Fig. 7). Clypeus and labrum with more abundant setation: some short macrosetae and several small setae.

Lacinia with bifurcate tip (there is a secondary subapical tooth) and, in addition to the prostheca, 4-5 hyaline lamellae and 7-9 setae (Fig. 6). Apical sensory cones of the galea equal in size or, in some specimens, one more developed than the other. Apical segment of the maxillary palp about 3 times longer than wide and 1.3-1.4 times longer than the third (Fig. 9). Apical segment of the labial palp very developed, about 1.7 times longer than wide and 1.4 times longer than the penultimate (Fig. 10). Inner side of this segment with 4-6 thin-walled basiconic sensilla; outer side with 3-6 (Figs 5 and 10).

Tibiae (Figs 12 and 13) with 1 dorsal, 1 lateral and 4 ventral spines; all tibial spines are shorter than the diameter of the article. The dorsal spine, inserted on the distal half of 

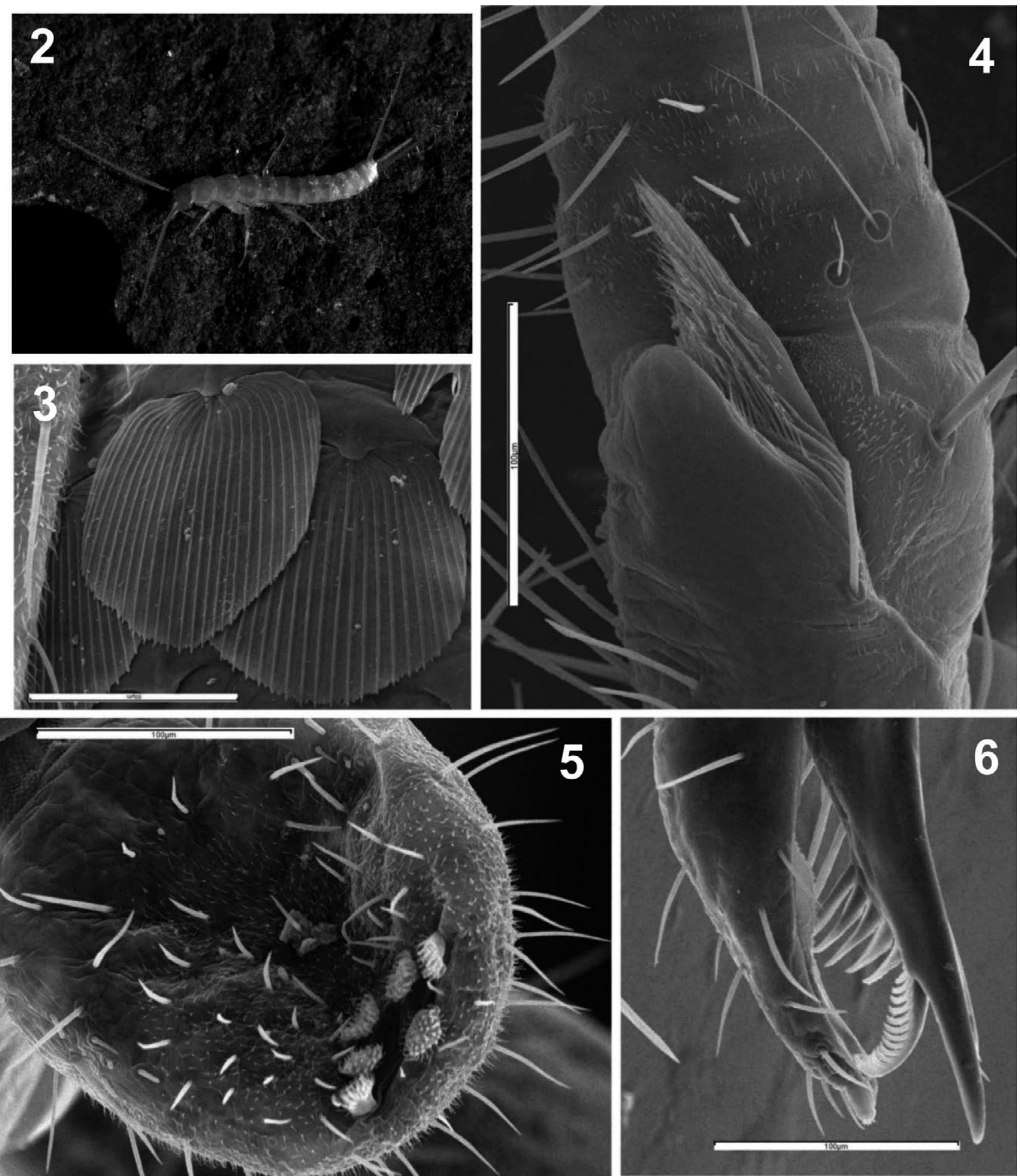

Figs 2-6. 2 - Canariletia holosterna gen. n. sp. n., photographed by P. Oromí; 3-6 - Canariletia holosterna gen. n. sp. n., SEM photographs of a male (paratype). 3 - scales; 4 - pedicellar apophysis; 5 - apical segment of labial palp; 6 - apex of galea and lacinia. Scales: $3-60 \mu \mathrm{m} ; 4-6-100 \mu \mathrm{m}$.

the tibia, is absent on metatibiae. Protibiae 3.4 times longer than wide; this ratio is about 4.3 for metatibiae.

Nota and urotergites as described for the genus, with 5-7 macrosetae on each lateral margin (more concentrated on posterolateral angles), alternating with several short bristles; the central part of the hind margin is devoid of setae (there are only $1+1$ sublateral macrosetae). The pronotum has 2-4+2-4 macrosetae on its anterior margin plus sev- eral short and thin setae. Longer macrosetae are about half the length of the notum (Fig. 11). Setation of the urotergites mainly concentrated on the posterolateral margin, the central portion of the posterior margin devoid of setae (at most, 1+1 submedian small bristles); macrosetae $(4-10+4-10$ on each urotergite) are irregularly arranged and their insertions alternate with short bristles (Fig. 15). Disc of urotergite $\mathrm{X}$ without setae in both sexes, the hind 


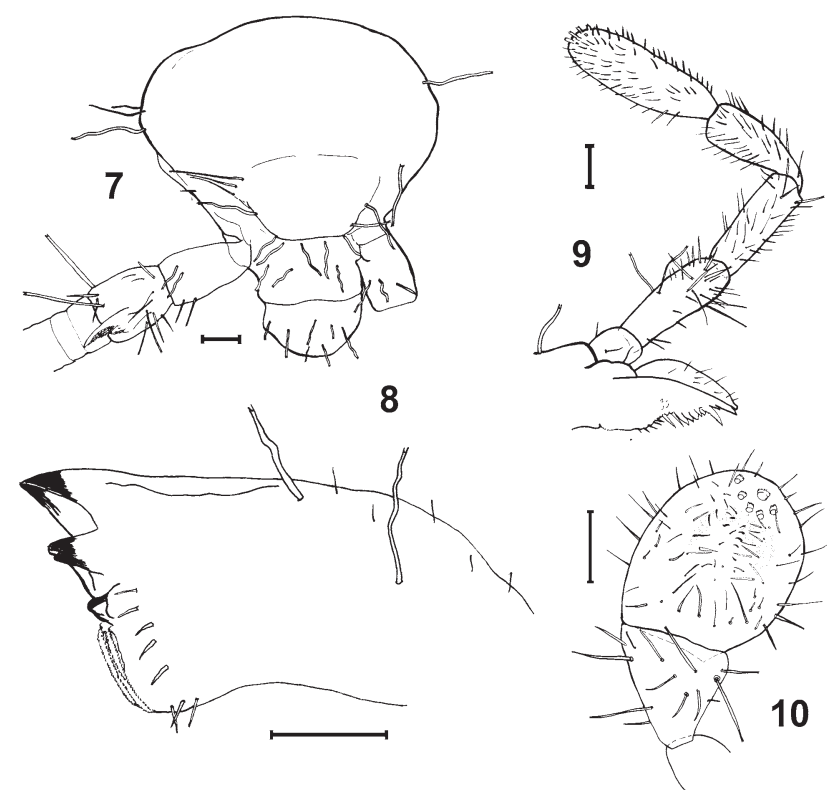

Figs 7-10. Canariletia holosterna gen. n. sp. n. 7 - head setation and basal divisions of antennae of a male (paratype); 8 mandible (paratype); 9 - maxillary palp (holotype); 10 - labial palp (holotype). Scales: $0.1 \mathrm{~mm}$.

margin of this tergite slightly concave (Figs 16 and 17); the concavity is slightly more pronounced in males. Urosternite I entire, without visible sutures, with a slightly convex hind border (Fig. 18). Hind border of the remaining sternites with $1+1$ submedian bifid macrosetae, $1+1$ sublateral macrosetae inserted very close to the insertion of styli and in the lateral portion external to the styli, some lateral acute setae (Fig. 19). Urosternites II-VI with exsertile vesicles and VII with pseudovesicles; urosternites II-IX with styli. Urosternite VIII of the male with a nearly truncated or slightly convex and not very protruding hind border (Fig. 20). Urosternite IX divided in two lateral portions (coxites) by a slightly marked suture. Penis small, with longitudinal opening. Parameres subcylindrical to ovoid, about 3.5-4 times longer than wide, slightly shorter than IX styli (Fig. 21). Coxite VIII of the female as in Fig. 22. Subgenital plate subtriangular, with convex hind margin, about 0.9 times longer than wide (Fig. 23). Ovipositor long, with about 20-22 divisions (basal divisions longer than wide, distal divisions shorter), surpassing the tips of styli IX by 2-3 times their length (Fig. 24); apex as in Fig. 25.

Type material. Holotype $\hat{\sigma}$, Canary Islands, Gran Canaria: Mina de los Llanetes (Valsequillo). 28R 607227 3170038. $163 \mathrm{~m}$ a.s.1., mounted on a slide. 10-II-2007. Data from the collector's label: TY-3829. GIET leg. Deposited in DZUL (Ref. 28501).

Paratypes (same locality and collectors):

TY-3087. 3-I-2007. $1 \delta^{\top}$ and 1․ Deposited in UCO, Ref. Z2254.

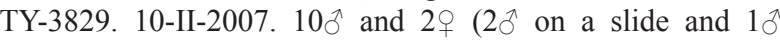
mounted for scanning deposited in UCO Ref. Z2255, $1 \delta^{\Uparrow}$ and 1 우 deposited in MNCN (Cat. Tipos $\mathrm{N}^{\mathrm{0}} 2350$ ), remaining males in alcohol deposited in DZUL Ref. 28502).

TY-3874. 1-VI-2007. $7 \hat{\delta}$ and 4ㅇ: $3 \hat{\delta}$ and 19 deposited in DZUL (Ref. 28503) $2 \delta$ and $1 \uparrow$ deposited in UCO (Ref, Z2256) and $2 \curvearrowright$ and $2 \circ$ deposited in IICT.
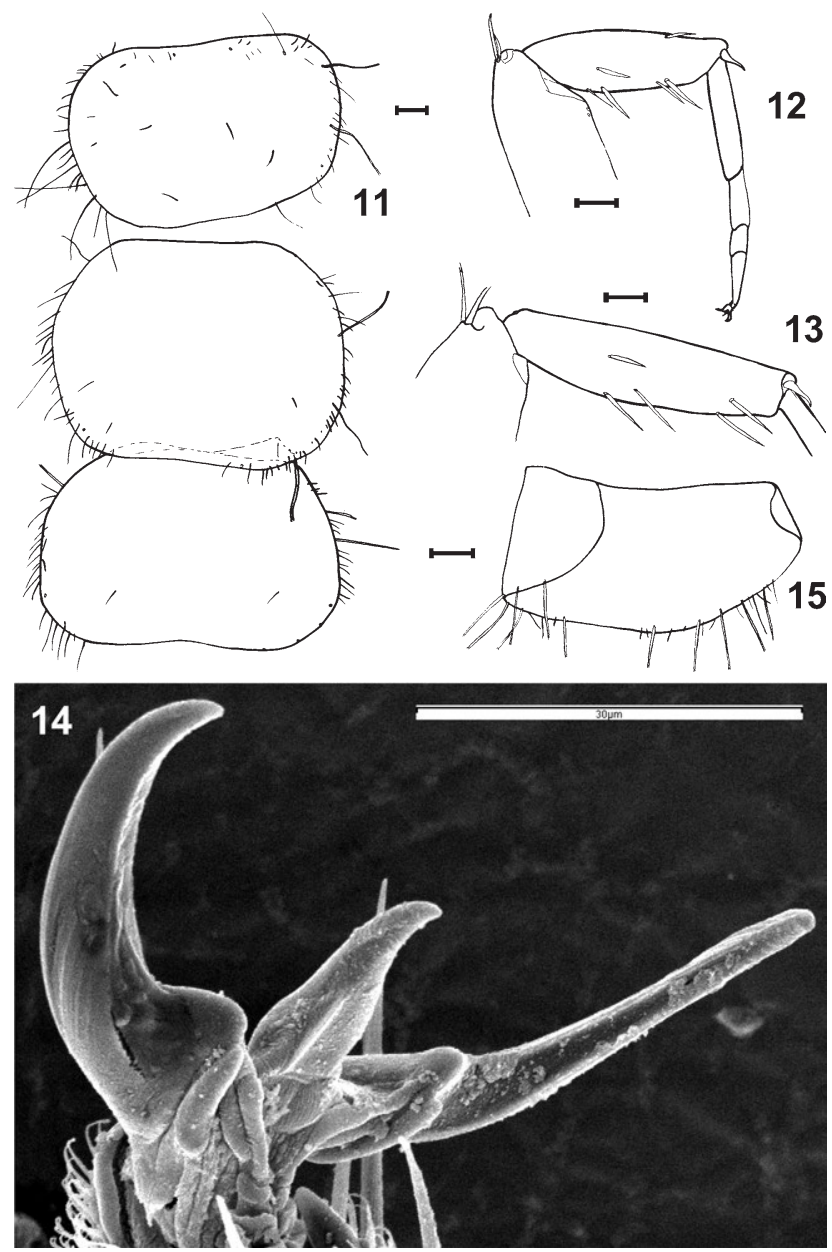

Figs 11-15. Canariletia holosterna gen. n. sp. n. 11 - nota of the holotype; 12 - protibia and tarsus (holotype); 13 - metatibia (holotype); 14 - Pretarsal claws (SEM photograph of a paratype); 15 - urotergite V (paratype). Scales: $11-13,15-0.1 \mathrm{~mm} ; 14-30$ $\mu \mathrm{m}$.

TY-3883. 6-VII-2007. $5 \AA$ and $3 \circ: 2 \hat{\circ}$ and $2 \circ$ (one of each sex dissected) deposited in UCO (Ref Z2257); remaining specimens deposited in DZUL (Ref. 28504).

Additional material. A juvenile specimen (length: $4 \mathrm{~mm}$ ) collected from Fuente Bebeideja (Gran Canaria), 16-V-2007, mounted on slide (TY-3862). This specimen was not included in the type series. Deposited in UCO, Ref. Z2258.

Etymology. From the Ancient Greek holos ("whole") and sternon ("chest, breast"), referring to the presence of entire urosternites, including the first one.

Habitat. This troglobiont species has been found in two underground artificial galleries excavated underneath dry riverbeds on Gran Canaria Island in order to collect phreatic water. The characteristics of these biotopes are described by Naranjo et al. (2009: 60-67), which include a map of Mina de los Llanetes (p. 70). This gallery has a relatively natural environment since it was dug a long time ago, thus the subterranean environment has recovered from the initial disturbance, and an abundance of various troglobionts belonging to other invertebrate groups occur there.

Discussion. Canariletia gen. $\mathrm{n}$. has a unique combination of characters, not shared by any other genus of Nicoletiidae. 


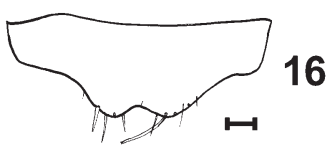

18
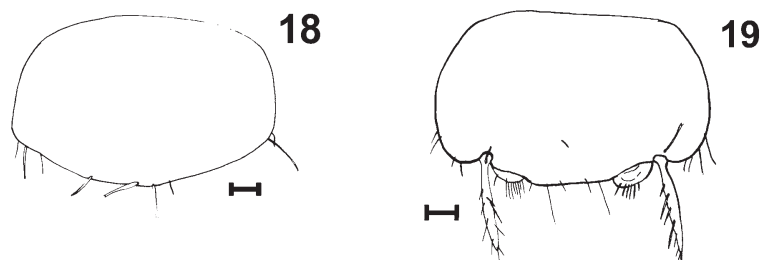

20
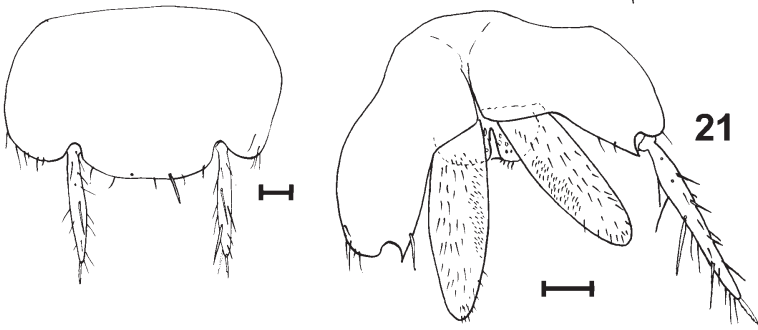

Figs 16-21. Canariletia holosterna gen. n. sp. n. 16-urotergite $\mathrm{X}$ of male (holotype); 17 - urotergite X of female; 18 - urosternite I (paratype); 19 - urosternite III (holotype); 20 - urosternite VIII (holotype); 21 - coxites IX, penis and paramera (holotype). Scales: $0.1 \mathrm{~mm}$.

Accepting a simple division in two subfamilies of the family Nicoletiidae, as Smith (1998) does, Canariletia can be placed in the subfamily Nicoletiinae, since this new genus has elongate body shape, long antennae and terminal filaments and subterranean habitat. It cannot be included in

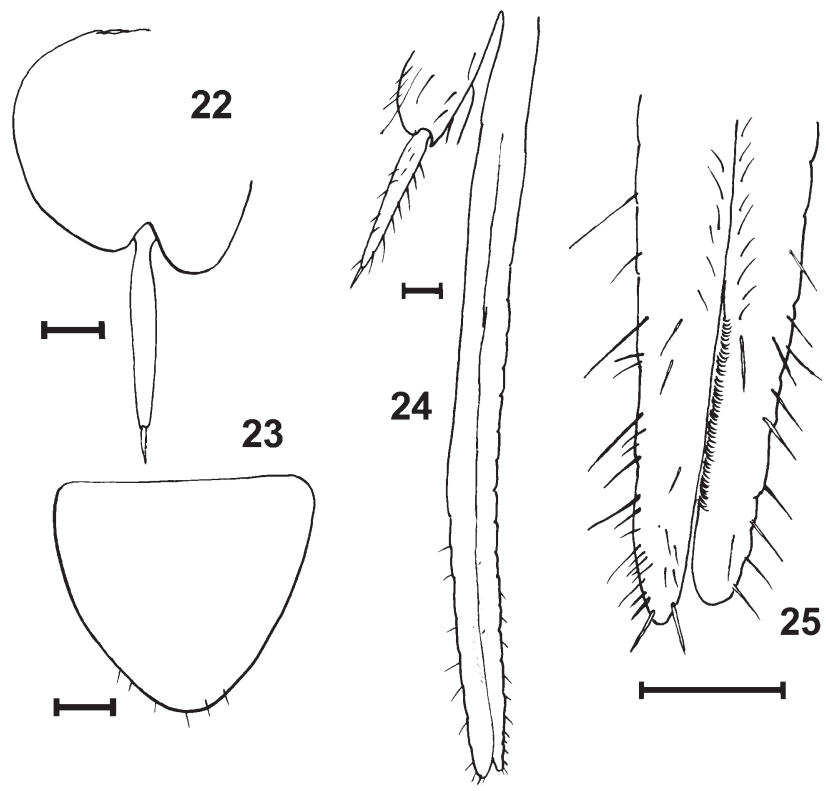

Figs 22-25. Canariletia holosterna gen. n. sp. n., female. 22 Coxite VIII; 23 - subgenital plate; 24 - coxite IX and ovipositor; 25 - apex of ovipositor. Scales: $0.1 \mathrm{~mm}$.

the subfamily Atelurinae, with short-bodied and myrmecophilic or termitophilic representatives.

If a more complex suprageneric classification is considered, such as that proposed by Mendes (1988), then this new genus does not fit the description of any of the subfamilies described, as is shown in Table 1.

In Canariletia, the pedicellar apophysis of the male shows a unique shape and structure, especially in terms of the distribution pattern of glandular setae on its surface. This glandular area is associated in some other genera

TABLE 1. Comparison of the characters of Canariletia gen. $n$. with those of four subfamilies of non-atelurine Nicoletiidae established by Mendes (1988), excluding Protrimenurinae, which is now considered to be an independent family.

\begin{tabular}{|c|c|c|c|c|c|}
\hline & Canariletia gen. $\mathrm{n}$. & Coletiniinae & Subnicoletiinae & Cubacubaninae & Nicoletiinae \\
\hline $\begin{array}{l}\text { Pedicellar apophyses in } \\
\text { males }\end{array}$ & $\begin{array}{l}\text { Present, distal, } \\
\text { inner side }\end{array}$ & Present, distal, inner side & $\begin{array}{l}\text { Absent. If present, } \\
\text { medial or basal }\end{array}$ & $\begin{array}{l}\text { Absent. If present, } \\
\text { basal or outer side }\end{array}$ & Absent \\
\hline Glandular area on pedicel & $\begin{array}{l}\text { Present, extensive, } \\
\text { associated with } \\
\text { the apophysis }\end{array}$ & $\begin{array}{c}\text { Associated with the apophysis, } \\
\text { usually with only a glandular } \\
\text { seta on an apical fovea }\end{array}$ & $\begin{array}{l}\text { Present, extensive, } \\
\text { not associated with } \\
\text { apophyses }\end{array}$ & $\begin{array}{c}\text { Present, extensive, } \\
\text { not associated } \\
\text { with apophyses }\end{array}$ & Absent \\
\hline $\begin{array}{l}\text { Pegs on urotergite } \mathrm{X} \text { of } \\
\text { males }\end{array}$ & Absent & Usually present & Absent & Absent & Absent \\
\hline $\begin{array}{l}\text { Pegs on terminal filaments } \\
\text { of males }\end{array}$ & Absent & Usually present & Variable & Absent & Absent \\
\hline $\begin{array}{l}\text { Urosternite I entire } \\
\text { (coxopodites fused with } \\
\text { the sternum) }\end{array}$ & Yes & No & Yes & Yes & No \\
\hline $\begin{array}{l}\text { Urosternites II-VII } \\
\text { composite (with sutures } \\
\text { separating coxopodites) }\end{array}$ & No & No & No & Yes & Yes \\
\hline $\begin{array}{l}\text { Number of pairs of } \\
\text { abdominal styli }\end{array}$ & 8 (II-IX) & 8 (7 in Lepidina $)$ & Variable (1-8) & 8 & 8 \\
\hline $\begin{array}{l}\text { Fusion of coxites IX on a } \\
\text { single sternite }\end{array}$ & No & No & Yes & Yes & Yes \\
\hline $\begin{array}{l}\text { Parameres simple (without } \\
\text { subdivisions or apical } \\
\text { modifications) }\end{array}$ & Yes & Yes & $\begin{array}{c}\text { No (only simple } \\
\text { in some Afrotropical } \\
\text { genera) }\end{array}$ & Yes (usually) & Yes \\
\hline
\end{tabular}




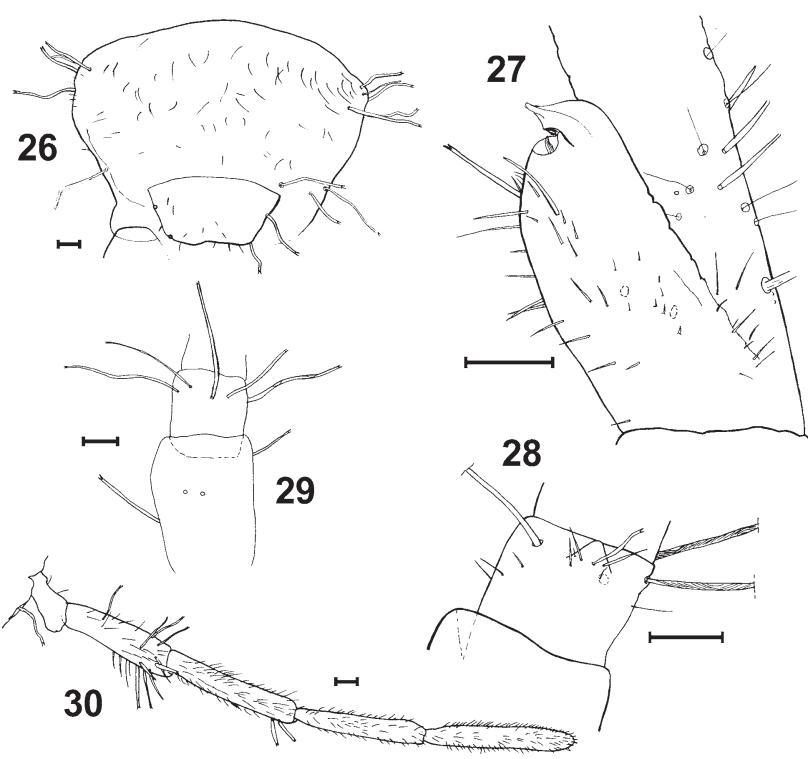

Figs 26-30. Coletinia majorensis sp. n. 26 - head; 27 - pedicellar apophysis of the left antenna of a male; 28 - pedicellar apophysis of the right antenna of a male; 29 - pedicel of female; 30 - maxillary palp. Scales: $0.1 \mathrm{~mm}$.

of Nicoletiidae (such as those included in the American subfamily Cubacubaninae) with the trunk of the antennal pedicel, and not the apophysis. Those genera bearing an apophysis with glands, such as the Palaearctic and most Afrotropical genera in this family, only have an apical fovea with a single glandular seta; Canariletia lacks fovea and has an extensive area of glands on one side of the projection of the apophysis.

From a geographic point of view, the new genus is related to those in the subfamily Coletiniinae, whose distributions are mainly Palaearctic and Afrotropical. For this reason, the Canarian new genus is compared with members of this group (Table 2). Canariletia shares with them the following characters: the arrangement of styli and vesicles on abdominal segments, a well developed subgenital plate in females, free coxites in males and simple parameres (without divisions or modifications), etc. All of these characters can be considered plesiomorphic in the Nicoletiidae (this is the argument against treating the group Coletiniinae

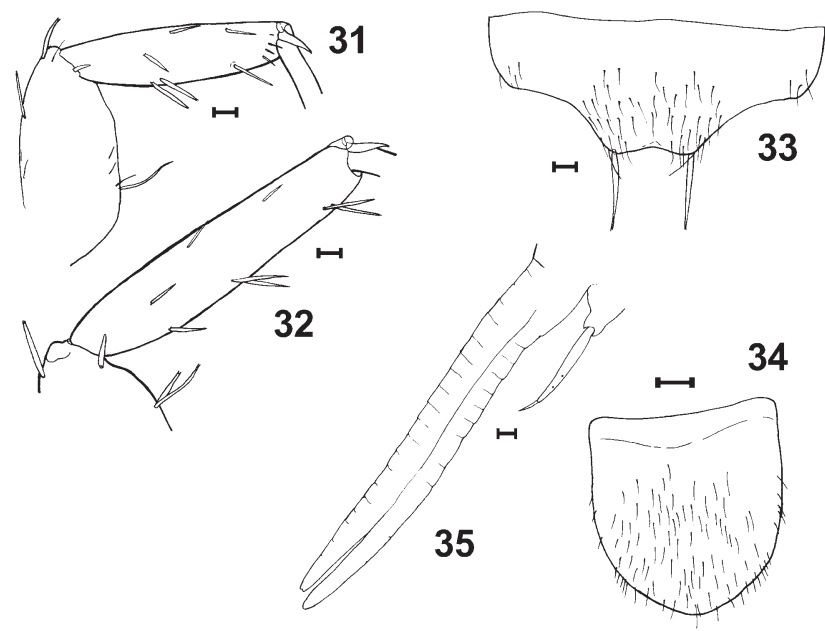

Figs 31-35. Coletinia majorensis sp. n. 31 - protibia; $32-$ metatibia; 33 - urotergite X of female; 34 - subgenital plate of female; 35 -ovipositor. Scales: $0.1 \mathrm{~mm}$.

as a valid subfamily from a phylogenetic point of view). However, in addition to the shape and structure of the pedicellar apophysis in males, Canariletia also fails in two important details in terms of the diagnosis of Coletiniinae presented by Mendes: the absence of division of urosternite I (Coletiniinae have sutures separating median sternum and lateral coxopodites) and the absence of sensorial pegs in the urotergite $\mathrm{X}$ of males (present in Coletiniinae). The exclusion of Canariletia of Coletiniinae is uncertain, because it is likely that characters in which the Canarian genus differs from this group of Old-World Nicoletiidae are autapomorphies. If Canariletia has to be included in the subfamily Coletiniinae, this suprageneric group needs to be redefined.

The absence of pregenital coxopodites in urosternites IVII (they have been described as "entire" since there are no evident sutures dividing the ventral plate into a sternum and two lateral sclerites) is probably an apomorphic character shared with members of the subfamily Subnicoletiinae, but in this group glandular apophyses are absent on the pedicel and the coxites IX are fused, which is not evident in the Canarian genus. Moreover, African genera assigned to Subnicoletiinae differ greatly from Canariletia in lacking

TABle 2. Comparison of Canariletia gen. n. with all Eurasian and African genera of non-Atelurinae Nicoletiidae (assignable to the subfamily Coletiniinae sensu Mendes). Characters shared by all of them are not included, but indicated in Table 1.

\begin{tabular}{|c|c|c|c|c|c|}
\hline & $\begin{array}{l}\text { Body length } \\
\text { of adults }\end{array}$ & Scales & $\begin{array}{l}\text { Sexual dimorphism in hind } \\
\text { margin of X urotergite }\end{array}$ & Empodium & $\begin{array}{c}\text { Pairs of } \\
\text { abdominal styli }\end{array}$ \\
\hline Canariletia gen. n. & $6-7 \mathrm{~mm}$ & $\begin{array}{l}\text { Present, typical, } \\
\text { with deep thin rays }\end{array}$ & Slight & Present & 8 \\
\hline Coletinia Wygodzinsky & $\mathrm{Up}$ to $20 \mathrm{~mm}$ & Absent & Pronounced & Present & 8 \\
\hline $\begin{array}{l}\text { Squamatinia } \text { Mendes } \\
\text { \& Reboleira }\end{array}$ & Up to $26 \mathrm{~mm}$ & $\begin{array}{c}\text { Present, modified, } \\
\text { without deep thin rays }\end{array}$ & Pronounced & Present & 8 \\
\hline Lepidina Silvestri & $6-7 \mathrm{~mm}$ & $\begin{array}{l}\text { Present and typical } \\
\text { (absent on head) }\end{array}$ & $\begin{array}{l}\text { Not described } \\
\text { (probably slight) }\end{array}$ & Present & 7 \\
\hline Lepidospora Escherich & Up to $19 \mathrm{~mm}$ & $\begin{array}{c}\text { Present and typical (absent on } \\
\text { head in the subgenus Brinckina) }\end{array}$ & Pronounced & Present & 8 \\
\hline Pseudobrinckina Mendes & $9.4 \mathrm{~mm}$ & $\begin{array}{l}\text { Present and typical } \\
\text { (absent on head) }\end{array}$ & Male unknown & Absent & 8 \\
\hline
\end{tabular}


scales (except in Hematelura), showing a strong tendency to have an ateluriform body shape, reduced number of abdominal vesicles and styli, only one apical conule on the galea, reduced subgenital plate in females, etc. So the relation of Canariletia with the subfamily Subnicoletiinae is even less probable. This group has its centre of distribution in the Southern Hemisphere (Neotropical, Afrotropical and Australasian regions) and is very heterogeneous in some characters that are stable in other subfamilies, so is probably paraphyletic or polyphyletic, as Mendes (op. cit .) and Smith (1998) suggest. Several genera of Afrotropical Subnicoletiinae are poorly studied; for example, Subnicoletia Silvestri, 1908 is only known from its original description and the whereabouts of the type are unknown, so it is difficult to update their relationships with recently described taxa.

For these reasons, the assignment of Canariletia gen. $\mathrm{n}$. to any of the previously described subfamilies of Nicoletiidae is not clear, so it can be considered as incertae sedis. Placing the Canarian new genus as an odd Coletiniinae is the most reasonable alternative to this provisional statement. But for a sure attribution, a world-wide revision of the suprageneric taxonomy of Nicoletiidae is needed.

\section{Coletinia majorensis Molero, Gaju, López \& Bach sp. n.}

\section{Description}

Body length up to $11 \mathrm{~mm}$. The tip of the abdomen of the holotype has been broken off and only the first $7 \mathrm{~mm}$ of the body are preserved. Habitus of the female as in Fig. 1.

Moderate spiralization of macrosetae in specimens mounted in Tendeiro medium. Head (Fig. 26) with relatively abundant minute setae, and a few bifid macrosetae: $2+2$ on the lateral margins of the frons, $3-4$ in the ocular region and $1-3$ on the genal region.

Antennae asymmetric in the male: the left pedicel shows a well developed apophysis; the right pedicel has a small triangular apophysis. The left apophysis is subcylindrical and nearly as wide as the diameter of the pedicel; the trunk of the apophysis bears a few short setae and two bifid macrosetae. On the apical region of the left apophysis there is a glandular seta inserted in a pit and a lamellar expansion curved above the pit; this expansion has a small sclerotized region in its concavity (Fig. 27). The right apophysis is subtriangular (Fig. 28), its width about 0.3 times the diameter of the pedicel and bearing few setae (one of them bifid). In females, the pedicel bears only 5 long bifid macrosetae (Fig. 29).

Apical segment of the maxillary palp about 7 times longer than wide and 1.2-1.3 times longer than the preceding article (Fig. 30). Labial palp as in other Nicoletiidae.

Protibiae (fig. 31) and mesotibiae 4.1-4.2 times longer than wide; this length/width ratio is $4.75-5.15$ for metatibiae (Fig. 32). All tibiae with 2 (sometimes 3) dorsal, 1 lateral and 4-5 ventral spines shorter than the diameter of the tibiae. Each tibia with two proximal spines ventrally inserted and one additional, short, subdistal spine.
Nota and urotergites as in other Nicoletiidae. Hind margin of urosternites with $1+1$ submedian and $1+1$ lateral macrosetae, and supplementary infralateral non-bifid long setae. There are also $1+1$ discal macrosetae.

The urosternite VIII, parameres, urotergite $\mathrm{X}$ and terminal filaments of the male are missing from the only male specimen available.

Urotergite $\mathrm{X}$ of females with abundant setae on the disc and a slightly concave hind margin; two long spines are inserted on the posterolateral angles (Fig. 33).

Subgenital plate semielliptical, about as long as wide or 1.1 times longer than wide, with rounded convex (slightly acute) hind margin (Fig. 34). Ovipositor with 22 divisions, exceeding the apex of stilus IX by more than 2.5 times the length of a stylus (Fig. 35).

Type material. Holotype $\widehat{\partial}$, Canary Islands, Fuerteventura, Villaverde, Cueva del Llano, 25-IV-2005, P. Oromí leg., incomplete specimen (abdominal tip missing) mounted on slide. Deposited in DZUL (Refs. LE-15 and 28505).

Paratypes: 3 f from the same locality: 1 mounted on a slide, $\mathrm{P}$. Oromí leg, (LE-14), 25-IV-2005, deposited in UCO (Ref. Z2259), and 2 i in alcohol, 9-XII-2004, S. Martín leg., deposited in IICT, and 19-IX-2007, P. Oromí leg., deposited in DZUL (Ref. 28506).

Etymology. The specific name is related to "majorero", a word that refers to anyone (or anything) from the island of Fuerteventura, where the species has been found.

Habitat. This species inhabits subterranean habitats suitable for troglobionts on Fuerteventura, an island with subdesertic climate and dry caves. It was recorded from only one cave, Cueva del Llano, in which it is probably not abundant given that very few specimens have been observed there although this cave has been visited on many occasions. Cueva del Llano is a remarkably old lava tube (about 900,000 years old) as these volcanic caves usually collapse or become silted after a few hundred thousand years (Howarth, 1973). The funnel-shaped area around the entrance facilitates the funnelling of occasional heavy rains into the cave, which forms temporary pools in its deeper parts (see Montserrat \& Romero, 1980). When the pools dry out, the clayish soil cracks; Coletinia majorensis sp. n. has been observed to take refuge in the clay fisures. Cueva del Llano is the only cave with some permanent moisture on Fuerteventura, and the only one that is occupied by a few troglobiont species (see Rando et al., 1993) such as Maiorerus randoi Rambla, 1993, an endangered harvestman recently protected by law. As Coletinia majorensis is even scarcer, it is very vulnerable to extinction and should also be legally protected, especially taking in account that Cueva del Llano is a show-cave with abundant visitors.

Discussion. The genus Coletinia Wygodzinsky, 1980 includes endogean or troglobiontic species found until now in the Mediterranean region, mainly in southern Europe. Only one species has been described from Brazil (Mendes \& Ferreira, 2002). Coletinia majorensis sp. n. represents the first record of this genus, not only for the Canary Islands but also for the Macaronesian region. Its diagnostic characters suggest that it is very close to Iberian species, mainly to those with asymmetric antennae. The closest species is probably C. asymetrica Bach et al., 1985, because 
the configurations of the pedicellar apophyses of males are very similar; compare Fig. 24 with the figures in Bach et al. (1985). However, C. asymetrica differs in the structure of the urotergite $\mathrm{X}$ of females, which has a straight hind margin and nearly lacks setae. The ovipositor of $C$. asymetrica has 33-35 subdivisions, whilst C. majorensis has only 22. Moreover, the ratio length/width of the apical segment of the maxillary palp is higher in the new species, but the ratio length of the apical segment/length of the preceding segment of this palp is higher in C. asymetrica.

Other species of Coletinia with asymmetric antennae in males are C. subterranea (Silvestri, 1902) and C. brasiliensis Mendes \& Ferreira, 2002, but the shape and development of the apophysis of the left antenna is clearly distinct in these species. Finally, the antennae of several species recently found in Southern Spain (Molero et al., 2013) are asymmetric, but the structure of their pedicellar apophyses is quite different.

ACKNOWLEDGEMENTS. We thank S. Martín, A. Lainez (GET Benisahare speleologic team), M. Naranjo, A.J. Pérez, C. González, H. López and S. de la Cruz for their help in sampling the caves where the new Nicoletiidae were found.

\section{REFERENCES}

Bach C., Mendes L.F. \& Gaju M. 1985: Sur une nouvelle espèce et une nouvelle citation de Nicoletiinae de Sierra Morena (Cordoue, Espagne) (Nicoletiidae, Zygentoma). - Boll. Soc. Entomol. Ital. 117(8/10): 132-140.

Howarth F.G. 1973: The cavernicolous fauna of Hawaiian lava tubes, I. Introduction. - Pac. Insects 15: 139-151.

MENDES L.F. 1982: Notas taxonómicas e zoogeográficas sobre os tisanuros (Microcoryphia e Zygentoma: Apterygota) macaronésicos. - Bol. Soc. Por. Entomol. (Supl. A) 1: 151-167.

Mendes L.F. 1988: Sur deux nouvelles Nicoletiidae (Zygentoma) cavernicoles de Grèce et de Turquie et remarques sur la systématique de la famille. - Rev. Suisse Zool. 95: 751-772.

Mendes L.F. 1993: New data on the thysanurans (Microcoryphia and Zygentoma: Insecta) from Northern Africa and from the Near East. — Garcia de Orta (Zool.) 18: 79-93.

Mendes L.F. 2002: On the status of the "protrinemurid" and "atelurid" thysanurans (Zygentoma: Insecta). - Bol. Soc. Portug. Entomol. 199: 201-212.

Mendes L.F. 2012: Description of the male of Lasiotheus Paclt, 1963, its implication in Atelurinae supra-generic taxonomy and keys for the genera (Insecta: Zygentoma). — Zootaxa 3573: $18-32$.

Mendes L.F. \& Ferreira R.L. 2002: On a new cave-dwelling Nicoletiidae (Zygentoma: Insecta) from Brazil. — Garcia de Orta (Zool.) 24: 101-106.

Mendes L.F., BaCh C. \& Gaju M. 1992: New data on the thysanurans fauna of the Canary Islands. I. Zygentoma. - Garcia de Orta (Zool.) 16: 195-203.

Mendes L.F., Molero R., Bach C. \& Gaju M. 1993: Novos dados sobre a fauna de tisanuros das ilhas Canárias. II. Notas e descrição de três novas espécies. - Garcia de Orta (Zool.) 19: 107-120.

Molero R., Bach C. \& Gaju M. 1999: Neoasterolepisma caeca, nueva especie de Lepismatidae de Canarias (Apterygota, Zygentoma). - Vieraea 27: 87-96.

Molero R., Gaju M. \& Bach C. 2000: On the taxonomic use of the distribution pattern of the antennal asteriform sensilla in Neoasterolepisma and Tricholepisma (Insecta, Zygentoma, Lepismatidae). - Pedobiologia 44: 248-256.

Molero R., Bach C., Sendra A., Montagud S., Barranco P. \& GaJu M. 2013: Revision of the genus Coletinia (Zygentoma: Nicoletiidae) in the Iberian Peninsula, with description of nine new species - Zootaxa 3615: 1-60.

MontSERRAT A. \& Romero M. 1980: Introducción al conocimiento vulcanoespeleológico de la isla de Fuerteventura (Islas Canarias). - Speleon 26: 93-98.

Naranjo M., Oromí P., Pérez A.J., GonzÁlez C., Fernández O., López H. \& Martín S. 2009: Fauna Cavernícola de Gran Canaria: Secretos del Mundo Subterráneo. S.E.C. Melansis, Gran Canaria, 106 pp.

NavÁs L. 1906: Catálogo descriptivo de los Insectos Neurópteros de las Islas Canarias. - Revta R. Acad. Cienc. Exact Fís. Nat. Madr. 4: 687-706.

Paclt J. 1963: Thysanura. Fam. Nicoletiidae. - Genera Insect. 216: 1-58.

PAClT J. 1966: Neue Beiträge zur Kenntnis der ApterygotenSammlung des Zoologischen Staatsinstitut und Zoologischen Museums Hamburg. II. Lepismatidae und Maindroniidae (Thysanura). Entomol. Mitt. Zool. Mus. Hamburg 3: 147-161.

Rando J.C., Sala L. \& Oromí P. 1993: The hypogean community of Cueva del Llano (Fuerteventura, Canary Islands). - Mém. Biospéol. 20: 189-193.

Reboleira A.S., Gonçalves F., Oromí P. \& Mendes L.F. 2012: Squamatinia algharbica gen. n. et sp. n., a remarkable new Coletiniinae silverfish (Zygentoma: Nicoletiidae) from caves in southern Portugal. — Zootaxa 3260: 33-46.

RiDLEY H.M. 1881: Notes on Thysanura collected in the Canaries and Madeira. — Entomol. Mon. Mag. 18: 14.

Silvestri F. 1940: Primo contributo alla conoscenza dei Tisanuri del Perù e descrizione di un genere e due specie dell' Argentina settentrionale. - Boll. Lab. Entomol. Portici 4: 444-458.

Sмітн G.B. 1998: Review of the Australian Nicoletiinae (Zygentoma: Nicoletiidae). - Invert. Taxon. 12: 135-189.

Ubero-Pascal N., Fortuño J.M. \& Puig M.A. 2005: New application for air-drying techniques for studying Ephemeroptera and Plecoptera eggs by Scanning Electron Microcopy. Microsc. Res. Tech. 68: 264-271.

WYGODZINSKY P. 1952: Notes on the Thysanura (Insecta, Apterygota) of the Canary Islands. Zool. Mededel. 31: 225-232.

WYGODZINSKY P. 1967: On the geographical distribution of the South American Microcoryphia and Thysanura (Insecta). In Delamare Deboutteville C. \& Rapoport E. (eds): Biologie de l'Amerique Australe. Vol. 3. Centre National de la Recherche Scientifique, Paris, pp. 505-524.

Received November 9, 2012; revised and accepted December 18, 2013 Prepublished online March 27, 2014 